УДК 338(09)

ББК 65.03

DOI $\underline{10.17150 / 2308-2588.2017 .18(1) \cdot 155-189}$

Ю. В. Латов

Институт социологии РАН, Финансовый университет при Правительстве РФ, г. МоскВа, Российская Федерация

\title{
ТВОРЧЕСКИЕ ЗАДАНИЯ ПО ЭКОНОМИЧЕСКОЙ ИСТОРИИ
}

Аннотация. В одном из самых первых выпусков «Историко-экономических исследований», в 2003 г., было отмечено, что задачники по экономической истории все еще отсутствуют «как класс». За прошедшие годы ситуация мало изменилась. В связи с этим автор предлагает для учебно-методического обеспечения преподавания экономической истории в вузах набор креативных заданий по материалам истории всех эпох, от древнего мира до новейшей истории. Эти задания рассчитаны на дискуссионное обсуждение. Они предполагают, что учащиеся отвечают на них не «сходу», а поискав дополнительную конкретную информацию по обозначенным в вопросах сюжетах. Вопросы построены на обсуждении сюжетов известных произведений искусства, объяснении «загадок истории», комментариях к исторической статистике и т. д.

Кююевые слова. Преподавание экономической истории в вузе, учебно-методическое обеспечение.

Yu. V. Latov

Institute of Sociology RAS, Financial University under the Government of the Russian Federation, Moscow, Russian Federation

\section{CREATIVE TASKS ON ECONOMIC HISTORY}

Abstract. In one of the first issues of «The Journal of Economic History \& History of Economics» in 2003 it was stated that there was no Economic history problem book. 
As for now, the situation hasn't changed. Hence, the author presents a set of creative tasks for methodological support of Economic history courses in universities, that touch on all epochs of human history. This tasks involve debates, require preliminary preparation, and are based on discussion of notable art masterpieces, explanation of historical mysteries and studying of historical data.

Keywords. Economic history teaching in universities, methodological support.

В одном из самых первых выпусков «Историкоэкономических исследований» было высказано критическое замечание, что «преподавание в России экономической истории, увы, отстало от преподавания economics`a лет на пять. С одной стороны, до сих пор нет учебников по экономической истории продвинутого уровня, которые бы соответствовали знаниям не студентов-первокурсников, а хотя бы экономистов-бакалавров. Что касается задачников по экономической истории, то они отсутствуют как класс» ${ }^{1}$. Хотя за минувшие полтора десятилетия многое изменилось, но, как не странно, «воз и ныне там»: в вузах России по-прежнему мало методологически продвинутых учебных пособий по экономической истории и нет задачников по данной дисциплине.

Такое затяжное отставание экономической истории как учебной дисциплины объясняют обычно тем, что экономическая история (или история) преподается в вузах на первом курсе, поэтому трудно предъявлять высокие требования к «зеленым» студентам, которые менее года назад окончили школу. Однако даже если забыть про более высокие уровни обучения, то можно вспомнить, что при преподавании экономики на первых курсах задачи используются очень широко (нередко можно встретить перегибы, когда семинары по эко-

1 Латов Ю. В. Занимательные задачи по экономической истории / Ю. В. Латов // Историко-экономические исследования. 2003. № 2-3. С. 184. 
номике превращаются в сплошной разбор типовых задач). Поэтому более чем странно, что за постсоветскую четверть века никто не собрал какую-либо «Рабочую тетрадь по экономической истории» с тестами и заданиями разных уровней сложности. Наличие спроса на такие задачи доказывается не только повседневной практикой преподавания, но и тем, что старые «Занимательные задачи по экономической истории» можно до сих пор найти в сети Интернет, причем вовсе не на серверах нашего журнала.

В данном выпуске «Историко-экономических исследований» мы предлагаем читателям новую «порцию» заданий по экономической истории, которые можно использовать как для текущих семинарских занятий, так и для финального контроля знаний. Представленные задания являются развернутыми. Они предполагают, что учащиеся отвечают на них не «сходу», а поискав дополнительную конкретную информацию по обозначенным в вопросах сюжетах. Вопросы рассчитаны на дискуссионное обсуждение; на некоторые из них принципиально нельзя дать однозначный ответ. Это - задания, предназначенные для развития креативных качеств учащихся.

В принципе задания рассчитаны на студентов-первокурсников экономических факультетов, хотя некоторые вопросы можно использовать для работы с вузовскими учащимися, имеющими более высокий уровень знаний. Чтобы задания можно было использовать в учебном процессе, к ним сознательно (в отличие от подборки задач в 2003 г.) не даны ответы.

\section{1. История древнего мира}

1.1. Одним из самых крупных памятников истории является Великая Китайская стена, протянувшаяся почти на 9 тыс. км. Утверждают даже, что это единственный рукотворный объект, который виден невооруженным глазом из космоса. 
Ответьте на следующие вопросы:

1. Когда и с какой целью эта стена была построена? Насколько успешно стена выполняла свою главную функцию?

2. Кто были строители Великой Китайской стены? Можно ли рассматривать ее как доказательство высокого развития рабства в Древнем Китае? Почему?

3. Некоторых историков удивляет, что Марко Поло не упоминал о Великой Китайской стене, хотя долгое время жил в Пекине, который был столицей Китая в период правления монголов. Ведь в наши дни туристы из Пекина доезжают до ближайших участков стены (например, до Бадалина) примерно за час. Из отсутствия упоминаний о стене у Марко Поло даже делают вывод, что знаменитый венецианец на самом деле в Китае не был, а просто выдумал свои путешествия. Однако большинство историков утверждают, что Марко Поло, будучи в Китае, и не мог видеть Великую Китайскую стену. Как они это объясняют?

4. Когда и почему Великая Китайская стена потеряла свое главное функциональное назначение?

1.2. Посмотрите на кадры из исторических блокбастеров про Александра Македонского. Обратите внимание, что хотя он гарцует на коне, но не опирается на стремя. Что это - показатель исключительной силы и ловкости знаменитого македонского полководца? Или же это надо объяснить иначе?

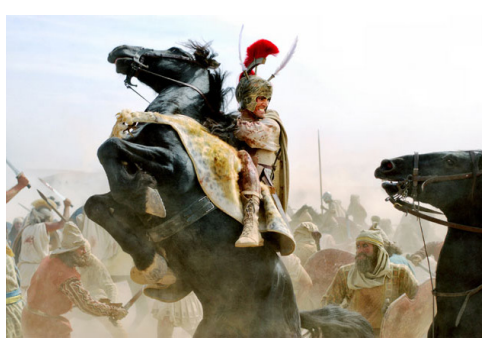

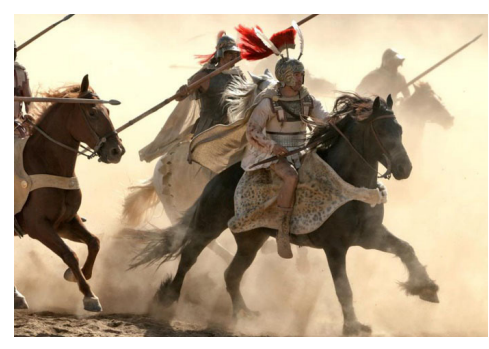

2017, vol. 18, no. 1, pp. 155-189 
Ответьте на следующие вопросы:

1. Когда и где было изобретено конное стремя? Когда оно стало применяться в Европе?

2. К каким изменениям в военном деле привело изобретение конного стремени?

3. Историки отмечают, что если в античную эпоху армии были многочисленными, их численность измерялась обычно десятками тысяч солдат, то в раннефеодальную эпоху численность армий резко упала, даже в самых крупных сражениях участвовало с обеих сторон лишь несколько тысяч рыцарей. Можно ли это объяснить последствиями изобретения конного стремени, или же у этого были другие причины?

4. К каким социально-экономическим последствиям привело изобретение конного стремени? Эти последствия были одинаковыми на Западе и на Востоке?

1.3. Одним из наиболее знаменитых экспонатов Национального археологического музея в Афинах является так называемый «антикитерский механизм», поднятый в начале XX в. с античного корабля, затонувшего в Эгейском море у острова Антикитера. Это устройство называют первым в мире компьютером, поскольку он, согласно современной реконструкции, позволял рассчитывать положения небесных тел, фазы Луны, даты религиозных праздников.

Ответьте на следующие вопросы:

1. Можно ли рассматривать находку этого механизма на корабле как доказательство того, что он использовался в навигации (наподобие астролябии)? Или корабль просто перевозил этот механизм?

2. Насколько уникальна эта находка? Известны ли другие примеры изобретения и практического применения «наукоемких» механизмов в античном мире?

3. Почему многие изобретения, которые делали в эпохи древнего мира и средневековья, часто «забывались», а с изобретениями последующих эпох этого уже 2017. T. 18, № 1. C. 155-189 
не происходило? Каковы специальные институты, направленные на фиксацию изобретений, даже если они не находят практического применения? Когда появились эти институты?

4. К первым имеющим практически-хозяйственное значение компьютероподобным механизмам относят изобретенный в самом начале XIX в. станок Жаккара, управляемый с помощью перфокарт. Что это был за станок, какое он имел значение для развития промышленности?

\section{2. История средних веков: зарубенные страны}

2.1. Самым первым в мире протестным выступлением наемных рабочих считают восстание чомпи во Флоренции в 1378 г., так что в следующем году можно будет отмечать 640-летие «борьбы пролетариата за свои права».

Ответьте на следующие вопросы:

1. Кто такие чомпи? Против кого они подняли восстание и чем оно закончилось? Когда и где произошли следующие крупные протестные выступления наемных рабочих?

2. Какие требования выдвигали восставшие? Насколько подобные требования типичны для последующих пролетарских протестных выступлений?

3. Можно ли считать это восстание началом классовой борьбы между классом предпринимателей и классом наемных рабочих?

4. Хотя первое «пролетарское» восстание произошло в Италии, самыми первыми странами, построившими капиталистическую экономику, стали совсем другие страны - Голландия и Англия. Как это объяснить?

5. В какой отрасли промышленной экономики в Италии раньше всего начало развиваться широкое использование наемного труда? Почему именно в этой отрасли? Совпадает ли это с закономерностями развития капитализма в Голландии и Англии? 


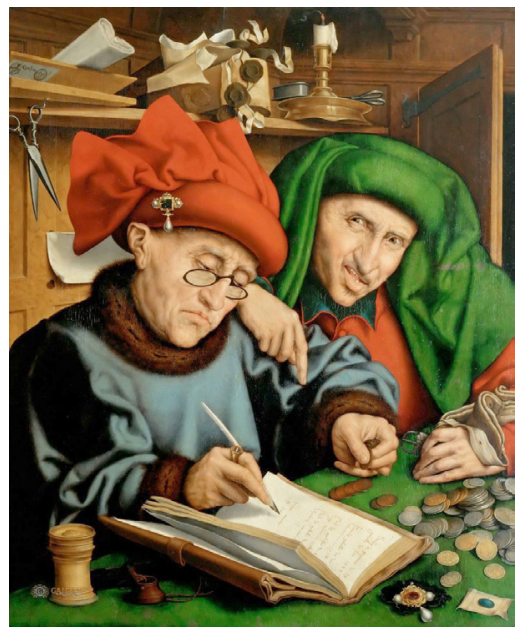

2.2. Посмотрите на картину «Менялы» средневекового фламандского художника Квентина Массейса (начало XVI в.).

Ответьте на следующие вопросы:

1. Какие функции выполняли средневековые менялы? Кем они обычно были по «основной профессии»? Как это отражено на картине?

2. Как в средние века оценивали моральность профессиональной деятельности, связанной с обслуживанием денежных операций? Как это отражено на картине? Почему эта картина Массейса пользовалась у современников большой популярностью и часто копировалась?

3. Сравните данную картину с другой, еще более известной, картиной Массейса «Меняла с женой»? Чем они друг от друга отличаются? Как это можно объяснить?

4. Случайно ли, что эта картина была написана во Фландрии? Какую роль в эпоху позднего средневековья играла Фландрия в развитии рыночного хозяйства? Как в дальнейшем развивались в этой стране социально-экономические отношения?

2.3. В 2015 г. в северо-немецком городе Любеке федеральный канцлер Германии Ангела Меркель в присутствии многочисленных гостей торжественно открыла Европейский музей Ганзы. Экспозиция поделена на четыре раздела, посвященные таким городам как Великий Новгород, Брюгге, Лондон и Берген.

Ответьте на следующие вопросы: 
1. Почему открытию этого музея придавалось такое большое значение, что его лично открыл руководитель правительства Германии?

2. Когда и почему возникла Ганза? Объясните в связи с этим, почему музейная экспозиция начинается с раздела о Великом Новгороде.

3. По какому принципу отобраны города, давшие название четырем основным разделам экспозиции? Это города, которые были членами Ганзы? Или с ними Ганзе приходилось бороться?

4. С кем и насколько успешно Ганзе приходилось воевать?

5. Когда и почему Ганза была ликвидирована? Какую роль в настоящее время играет так называемая Новая Ганза?

\section{3. История средних веков: Россия}

3.1. Посмотрите на картину «Баскаки» русского художника-передвижника С. В. Иванова (1909 г.).

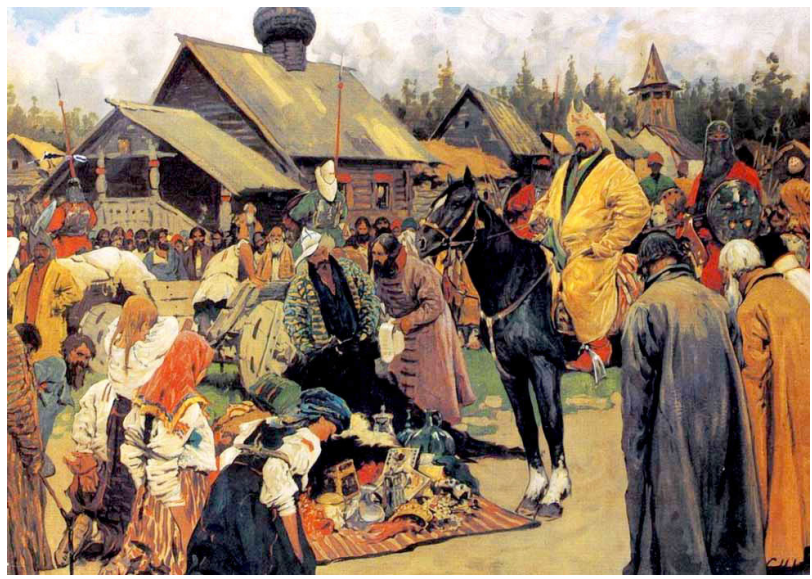

Ответьте на следующие вопросы:

1. К какому периоду «монголо-татарского игра» относится сюжет этой картины? Подсказка: когда дань в русских княжествах собирали баскаки, а когда это стали делать сами русские князья? 
2. Кто такие баскаки? Каковы их функции? Где происходит действие картины - в городе или в селе?

3. Дань легче всего собирать деньгами (монетами), однако на картине монет не видно, вместо этого рабы (на переднем плане), иконы в дорогих окладах, посуда (на ковре). Как это можно объяснить?

4. На основании чего правители Золотой Орды устанавливали размер дани?

5. Пытаясь оценить относительные размеры дани Золотой Орде, современные историки приходят к выводу, что она была относительно невелика - то ли $10 \%$, то ли даже 1,5-2 \% от доходов. Однако, согласно русским летописям, сбор ордынской дани был сопряжен с большими трудностями. Как это объяснить?

6. В XIII-XIV вв. русские князья отчаянно боролись друг с другом за право получить ярлык на Великое Владимирское княжество, обладатель которого отвечал перед ханами Золотой Орды за регулярную выплату дани. Зачем они боролись за ярлык, если задержка в выплате дани могла привести к смерти «нерадивого» князя?

3.2. В 1570 г. московский царь Иван IV Грозный отправил английской королеве Елизавете дипломатическое письмо, в котором писал: «...Вели переговоры с нашим послом твои бояре только о торговых делах, управляли же всем делом твои купцы... Мы думали, что ты в своем государстве государыня и сама владеешь и заботишься о своей государевой чести и выгодах для государства, - поэтому мы и затеяли с тобой эти переговоры. Но, видно, у тебя, помимо тебя, другие люди владеют, и не только люди, а мужики торговые, и не заботятся о наших государских головах и о чести и о выгодах для страны, а ищут своей торговой прибыли».

Ответьте на следующие вопросы:

1. С какой целью Англия вела дипломатические переговоры с Московским царством? Как это связано 2017. T. 18, № 1. C. 155-189 
с общим развитием отношений Западной Европы со странами Востока в XV-XVII вв.?

2. Что вызвало негодование Ивана Грозного? Связано ли это с проявлением пренебрежения англичан к России?

3. Кто такие «мужики торговые», о которых писал Иван Грозный? Какую роль они играли в российско-английских отношениях?

4. Чем завершились российско-английские переговоры при Иване Грозном? Как отношения между этими странами развивались в последующие десятилетия, до эпохи Петра I?

5. В центре Москвы есть небольшой музей - «Старый английский дворик». Как он связан с перепиской Ивана Грозного и Елизаветы?

6. Каковы различия между развитием российско-английских отношений и развитием отношений Англии с другими сильными восточными странами (например, с империей Великих Моголов в Индии)?

3.3. В таблице показаны результаты исследований советских историков Е. П. Борисенкова и В. М. Пасецкого по исторической климатологии.

\begin{tabular}{|r|r|r|r|r|}
\hline \multirow{2}{*}{ Периоды } & \multicolumn{2}{|c|}{ Англия } & \multicolumn{2}{c|}{ Россия } \\
\cline { 2 - 5 } & наводнения & \multicolumn{1}{|c|}{ засухи } & наводнения & \multicolumn{1}{c|}{ засухи } \\
\hline \multicolumn{5}{|c|}{ Малый климатический оптимум } \\
\hline $1000-1099$ & 1 & 1 & 2 & 1 \\
\hline $1100-1199$ & 3 & 1 & 1 & 1 \\
\hline $1200-1299$ & 5 & 2 & 5 & 1 \\
\hline \multicolumn{5}{|r|}{ Малый ледниковый период } \\
\hline $1300-1399$ & 3 & 0 & 8 & 11 \\
\hline $1400-1499$ & 3 & 1 & 13 & 11 \\
\hline $1500-1599$ & 3 & 3 & 10 & 6 \\
\hline $1600-1699$ & 1 & 3 & 9 & 4 \\
\hline Всего & 19 & 11 & 48 & 35 \\
\hline
\end{tabular}

Ответьте на следующие вопросы:

1. Какое значение имеют погодно-климатические условия для социально-экономического развития доиндустриального общества? 
2. Насколько велики были колебания климата на протяжении второго тысячелетия нашей эры? Найдите информацию, насколько сильно отличались среднегодовые температуры малого ледникового периода от температур периода малого климатического оптимума?

3. Насколько сильно, согласно таблице, различались частоты климатических бедствий в Англии и в России в разные периоды? Как это можно объяснить?

4. Можно ли утверждать, что малый ледниковый период задержал переход от феодализма к капитализму в Англии и/ или в России?

5. Насколько в современную эпоху (XX-XXI вв.) сохраняется зависимость социально-экономического развития общества от изменений климата?

\section{4. История нового времени: зарубежные страны}

4.1. На схеме показана смена технологических укладов в интерпретации современного российского экономиста С. Ю. Глазьева.

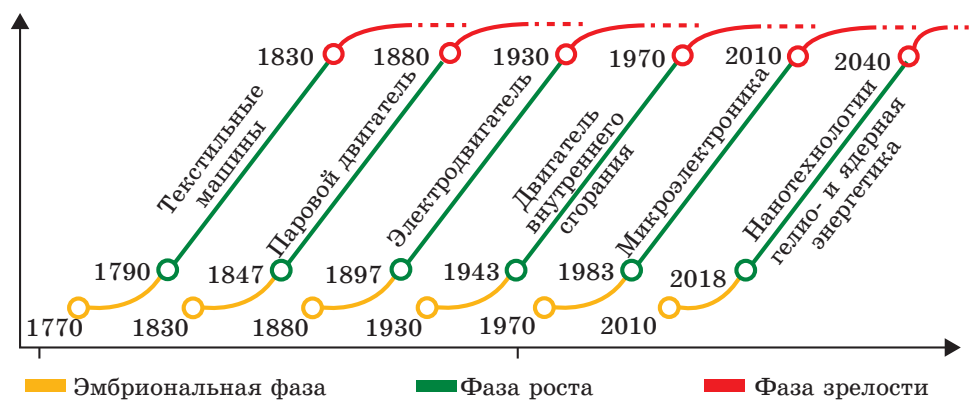

Ответьте на следующие вопросы:

1. Что такое «технологический уклад»? Почему их смена началась только с рубежа XVIII-XIX вв.?

2. Концепция какого знаменитого русско-советского экономиста, репрессированного в 1930-е гг., лежит в основе концепции смены технологических укладов? Какая именно взаимосвязь с его концепцией? 
3. Как объясняют ритмичность смены технологических укладов? Как можно объяснить ускорение ритма (интервал между генезисом 1-го и 2-го укладов 60 лет, а между 5-м и 6-м - только 40)?

4. Как соотносятся перечисленные в схеме 5 укладов и такие понятия как «промышленная революция», «вторая промышленная революция», «НТР»?

5. Описывает ли эта модель развитие только ведущих стран или же с ее помощью можно изучать и историю стран догоняющего развития (включая Россию)?

4.2. В литературе можно встретить две противоположные интерпретации так называемых опиумных войн, которые вели против Китая (Цинской империи) западные державы (Великобритания и Франция) в 1840-1842 гг. и 1856-1860 гг. Одни считают их насильственной империалистической агрессией, другие защитой свободы торговли.

Ответьте на следующие вопросы:

1. Почему эти войны называются «опиумными»? Чего требовали европейцы от правительства Китая? Удалось ли им добиться выполнения своих требований?

2. Почему для развитых стран в XIX в. большое значение имело обеспечение свободы торговли вообще и торговли с Китаем в частности?

3. Почему англичане продавали в Китай в основном опиум? Какую роль в XIX в. играл опиум в потребительском поведении китайцев и европейцев? Когда и почему торговля им была запрещена? Когда и как Китаю удалось справиться с «повальной» наркоманией?

4. Почему европейцы во время этих войн постоянно наносили поражения китайцам, хотя китайская армия была гораздо многочисленнее и тоже вооружена огнестрельным оружием?

5. Сравните опиумные войны с вторжением европейских держав в Мексику в 1861-1867 гг. Чем 
схожи мотивы этих интервенций? Почему мексиканцам, в отличие от китайцев, удалось дать отпор интервентам?

6. Откуда англичане везли в Китай опиум? Кто получал выгоду от этой торговли кроме самой Великобритании?

4.3. Американский экономист российского происхождения Саймон Кузнец в 1950-х гг. сформулировал концепцию «кривой Кузнеца» (см. рисунок), согласно которой после промышленной революции сначала одновременно растут средние доходы и их дифференциация, но потом рост доходов сопровождается снижением их дифференциации.

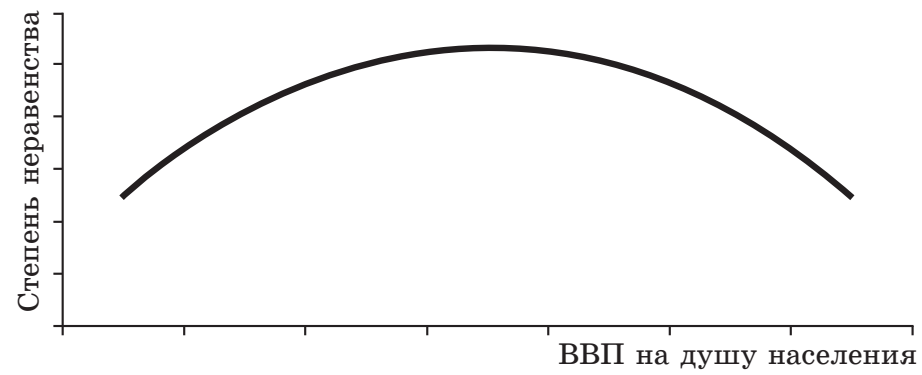

Ответьте на следующие вопросы:

1. Какими конкретно-историческими данными и по каким странам можно подтвердить эту модель? Есть ли данные исторической статистики, которые опровергают «кривую Кузнеца»?

2. Как можно объяснить эту модель? Какие факторы способствуют и какие противодействуют ее реализации?

3. Если рост средних доходов дополняется их сильной дифференциацией, то нельзя ли утверждать, что на ранних этапах развития индустриального общества все выгоды от развития получают только господствующие классы, а жизнь работников не улучшается или даже откровенно ухудшается? 
4. Каковы максимальные показатели дифференциации доходов (коэффициент Джини, децильный коэффициент) в индустриальных странах?

5. Можно ли с помощью этой модели объяснить какие-то закономерности истории России, или же «кривая Кузнеца» относится только к странам Запада?

\section{5. История нового времени: Россия}

5.1. На графике показана динамика доли прямых военных расходов в государственном бюджете России с конца XVIII в. до конца XXв., согласно данным А. Гольца.

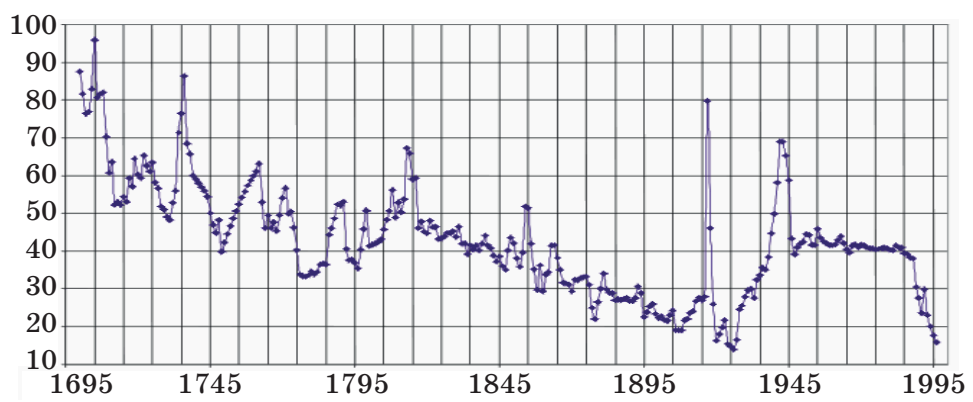

Ответьте на следующие вопросы:

1. Как можно объяснить отраженные на графике долгосрочные тенденции динамики относительных военных расходов - сначала нисходящий тренд с конца XVII в. (80-90 \%) до начала XX в. (20-30 \%), потом скачок и колебание на устойчиво-высоком уровне $(40 \%)$ и резкий спад в конце $\mathrm{XX}$ в.?

2. Высокий уровень военных расходов (порядка 50 \% госбюджета) формируется в России только в эпоху Петра I, или же он был высоким и в период Московского царства? Найдите оценки военных расходов Московского царства XVI-XVII вв. в работах классиков (Ключевского, Соловьева и др.).

3. Какие войны, которые вела Россия в XVIII-XX вв., привели к «скачкам» военных расходов, а какие не привели? Как это можно объяснить? 
4. Является ли отраженный на графике уровень военных расходов спецификой развития России, или же аналогичные тенденции были в других странах? Попробуйте найти информацию о доле военных расходов в госбюджетах в эпоху нового времени по, например, Великобритании и Франции.

5.2. В таблице показано соотношение ВВП России и разных стран мира в 1700, 1820 и 1913 гг., согласно оценкам А. Мэддисона.

\begin{tabular}{|l|r|r|r|r|r|r|}
\hline \multirow{2}{*}{ Соотношения } & \multicolumn{3}{|c|}{ ВВП в целом } & \multicolumn{3}{c|}{$\begin{array}{c}\text { ВВП на душу } \\
\text { населения }\end{array}$} \\
\cline { 2 - 8 } & $\mathbf{1 7 0 0}$ г. & $\mathbf{1 8 2 0}$ г. & $\mathbf{1 9 1 3}$ г. & $\mathbf{1 7 0 0}$ г. & $\mathbf{1 8 2 0}$ г. & $\mathbf{1 9 1 3}$ г. \\
\hline Россия/США & 3078,2 & 301,0 & 44,9 & 116,0 & 54,8 & 28,1 \\
\hline Россия / Китай & 19,6 & 16,5 & 96,3 & 101,8 & 114,8 & 269,6 \\
\hline Россия/Индия & 17,7 & 33,8 & 113,8 & 90,0 & 129,3 & 221,1 \\
\hline Россия/Япония & 105,2 & 182,1 & 324,1 & 107,2 & 103,0 & 107,3 \\
\hline Россия/Франция & 76,4 & 98,2 & 160,8 & 62,0 & 56,0 & 42,6 \\
\hline $\begin{array}{l}\text { Россия/ Велико- } \\
\text { британия }\end{array}$ & 151,4 & 104,1 & 103,5 & 48,9 & 40,9 & 30,2 \\
\hline Россия/Германия & 120,9 & 143,3 & 97,9 & 68,3 & 65,1 & 40,8 \\
\hline Россия/Италия & 111,0 & 167,6 & 243,0 & 55,6 & 61,7 & 68,0 \\
\hline
\end{tabular}

Ответьте на следующие вопросы:

1. Какие показатели - ВВП или среднедушевой ВВП - лучше использовать при сравнениях уровня развития разных стран? Почему?

2. Какие страны в период 1700-1913 гг. считались наиболее передовыми (лидерами капиталистической мир-экономики), а какие - отстающими? С какими из них лучше сравнивать Россию для понимания результатов ее модернизации в период от реформ Петра I до Первой мировой войны?

3. Как менялся разрыв между Россией и перечисленными в таблице странами Запада? Объясните эти тенденции.

4. Как менялся разрыв между Россией и перечисленными в таблице странами Востока? Объясните это. 
5. Согласно таблице, во время Отечественной войны 1812 г. среднедушевой ВВП России составлял лишь примерно 50 \% от среднедушевого ВВП Франции, а во время русско-японской войны 1904-1905 гг. российский среднедушевой ВВП был выше японского. Однако Отечественную войну 1812 г. Российская империя успешно выиграла, а русско-японскую «с треском» проиграла. Как это можно объяснить?

5.3. В произведениях А. С. Пушкина нередко встречаются критические высказывания по поводу системы крепостного права и эксплуатации помещиками крепостных крестьян. Например, в стихотворении «Деревня» (1819 г.) он писал, что «Здесь барство дикое, без чувства, без закона, Присвоило себе насильственной лозой И труд, и собственность, и время земледельца. Склонясь на чуждый плуг, покорствуя бичам, Здесь рабство тощее влачится по браздам Неумолимого владельца». А в «Евгении Онегине» в 1820-е гг. Пушкин писал про своего персонажа, что «Ярем он барщины старинной Оброком легким заменил; И раб судьбу благословил».

Ответьте на следующие вопросы:

1. Пушкин, как видно по приведенным цитатам, постоянно сравнивает крепостничество с рабством. Это - поэтическое преувеличение, или для этого были основания? Каковы черты сходства и различия между положением негра-раба в Соединенных Штатах и крепостного в России в первой половине XIX в.?

2. Почему замена барщины оброком рассматривается как облегчение для крепостных? Свяжите ответ на этот вопрос с анализом участия помещиков и крепостных крестьян в рыночных отношениях.

3. Что означает «чуждый плуг»? Можно ли это истолковать как указание на то, что крепостные использовали сельхозинвентарь, принадлежащий помещику? 
4. Можно ли согласиться с утверждением, что помещики «без закона» присвоили «и труд, и собственность, и время земледельца»? Были ли у крепостных крестьян какие-либо права собственности?

5. Насколько широко было распространено в России в первой половине XIX в. осуждение крепостного права, как у Пушкина? Почему?

6. А что известно о самом А. С. Пушкине как о помещике? Сколько он имел крепостных? Какие формы эксплуатации применялись в его имениях?

\section{6. История новейшего времени: зарубежные страны}

6.1. Наряду с обычными (локальными) эпидемиями специалисты сферы здравоохранения выделяют также пандемии - широкомасштабное распространение смертельно опасных заболеваний, несущее угрозу депопуляции нескольким странам или даже всему человечеству. Последней крупной пандемией называют испанским грипп («испанку»), которым в 1918-1919 гг. переболело примерно $1 / 4$ населения планеты и от которого умерло не менее 50 млн человек.

Ответьте на следующие вопросы:

1. Сравните потери человечества от «испанки» с потерями в ходе Первой мировой войны. Почему военные потери измерены лучше, чем потери от болезни?

2. До «испанки» по всей Европе в последние два столетия прошло еще две пандемии, которые оказали существенное влияние на историю человечества. Назовите эти эпидемии. Каковы были их последствия?

3. Хотя пандемия «испанки» унесла больше жизней, чем предыдущие пандемии, однако с ее последствиями удалось быстрее справиться. Почему?

4. B XVI в. индейское население Америки сократилось в несколько раз из-за пандемий, хотя европейские колонизаторы от них практически не болели. Как это объяснить? Были ли подобные пандемии при колониальных захватах в других регионах планеты? 
5. Какие факторы препятствуют (или даже блокируют) повторение в XXI в. пандемий? А какие факторы, наоборот, повышают их опасность?

6. Какова связь между борьбой человечества с эпидемиями и концепцией «Великого побега» современного британо-американского экономиста А. Дитона, лауреата премии им. А. Нобеля?

6.2. В таблице показаны количественные характеристики самых крупных циклических кризисов по США в период до Великой депрессии включительно.

\begin{tabular}{|l|r|r|r|r|r|}
\hline \multicolumn{1}{|c|}{ Показатели } & 1883-1884 & 1893-1894 & 1907 & 1920-1921 1929-1933 \\
\hline $\begin{array}{l}\text { Продолжитель- } \\
\text { ность (от начала } \\
\text { кризиса до его низ- } \\
\text { шей точки), месяцев }\end{array}$ & 20 & 13 & 6 & 9 & 44 \\
\hline $\begin{array}{l}\text { Сокращение еже- } \\
\text { месячного произ- } \\
\text { водства чугуна, \% }\end{array}$ & 48 & 58 & 54 & 74 & 86 \\
\hline $\begin{array}{l}\text { Сокращение сто- } \\
\text { имости акций } \\
\text { промышенных } \\
\text { корпораций, \% }\end{array}$ & 45 & 55 & 49 & 47 & 89 \\
\hline
\end{tabular}

Ответьте на следующие вопросы:

1. С какого времени начались экономические циклические кризисы перепроизводства? Чем они отличались от предыдущих не-циклических экономических кризисов (типа, например, тюльпанного кризиса в Голландии в 1637 г.)

2. Есть ли какая-то общая тенденция в изменении силы кризисов перепроизводства (усиление, ослабление, стабильность)?

3. Из таблицы видно, что Великая депрессия феноменальна не столько по глубине спада, сколько по его продолжительности. Как это можно объяснить?

4. Были ли впоследствии в развитых странах экономические кризисы, близкие по продолжительности и глубине с кризисами до Второй мировой войны? Почему? 
5. Можно ли с перечисленными кризисами сопоставить российский кризис 1990-х гг.? А кризис 2014-2016 гг.?

6.3. Посмотрите на картину американского художника Джона Саржента «Отравленные газами» (1919 г.).

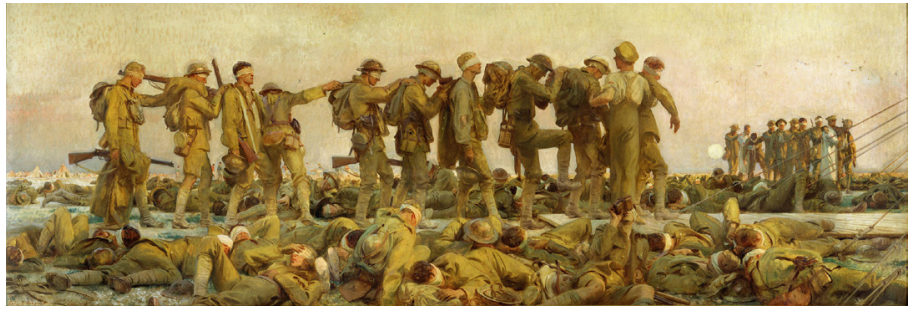

Ответьте на следующие вопросы:

1. Отравляющие газы считаются одним из символов Первой мировой войны и вообще ужасов, приносимых технологическим прогрессом. А применялись ли отравляющие газы до Первой мировой войны? Почему?

2. Какое влияние оказала эта технологическая инновация на ход боевых действий? Как и благодаря кому удалось ее хотя бы частично нейтрализовать? Подсказка: на картине в руках одного из солдат есть это изобретение.

3. Какие еще технологические инновации и насколько успешно применялись во время Первой мировой войны? Можно ли утверждать, что именно благодаря их применению Антанте удалось в конце концов победить противника?

4. Почему отравляющие газы не применялись в последующих войнах (включая Вторую мировую войну)?

\section{7. История новейшего времени: Россия}

7.1. На графике показаны альтернативные пути развития советской экономики в 1928-1939 гг. (ускоренная индустриализация без коллективизации, 
«длинный» НЭП, модель Харриса-Тодаро), согласно модели, разработанной современным канадским историком-экономистом Робертом Алленом.

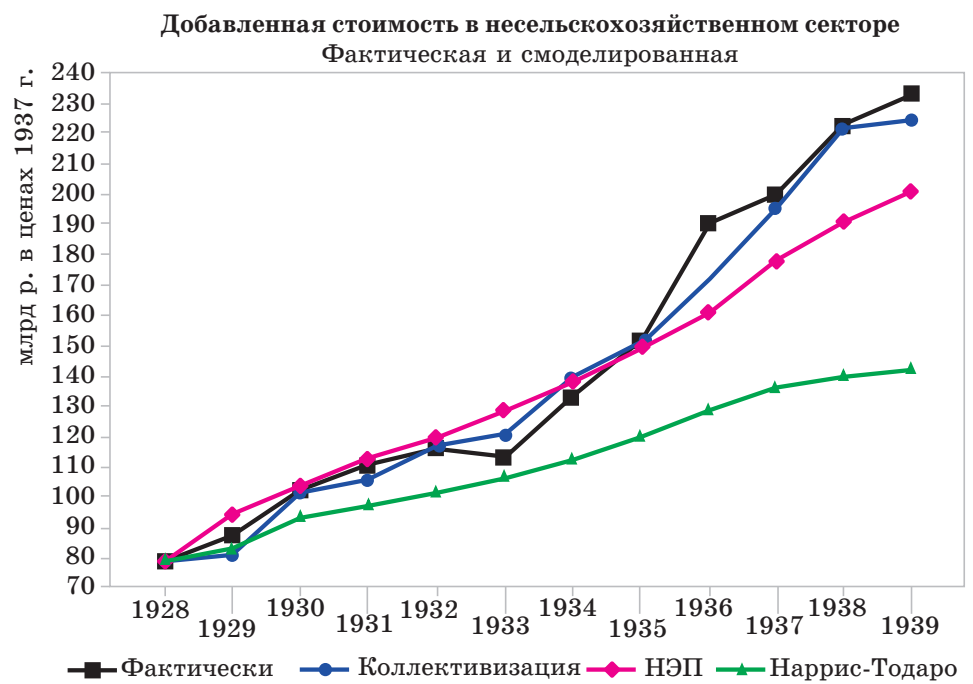

Ответьте на следующие вопросы:

1. Объясните сущность рассматриваемых Р. Алленом альтернатив фактически произошедшему Великому перелому.

2. Каковы сравнительные результаты рассмотренных Р. Алленом вариантов развития?

3. В современной науке популярна точка зрения, что коллективизация - создание системы принудительного выкачивания ресурсов из деревни ради подъема городской промышленности - была в СССР неизбежна, поскольку больше неоткуда было взять ресурсы. А что по этому поводу полагает Р. Аллен?

4. На примере модели Р. Аллена объясните достоинства и недостатки контрфактического моделирования как метода исторических исследований.

7.2. Символами истории России являются расположенные в Кремле Царь-пушка (отлита в конце 
XVI в.) и Царь-колокол (отлит в XVIII в.). Менее известен другой символ - находящийся в музее атомного оружия в г. Сарове (бывшем Арзамасе-16) макет так называемой Царь-бомбы - самой мощной (более 50 мегатонн в тротиловом эквиваленте) бомбы за всю историю человечества. Если Царь-пушка и Царь-колокол никогда практически не применялись, то Царь-бомба была взорвана во время плановых испытаний в 1961 г. на Новой Земле.

Ответьте на следующие вопросы:

1. Можно ли рассматриваться советский атомный проект как демонстрацию успехов развития в СССР высоких технологий?

2. Оказывал ли советский атомный проект в целом и испытания ядерного оружия в частности какое-либо влияние на развитие гражданских отраслей экономики?

3. Каковы особенности социально-экономического развития г. Арзмас-16, где была разработана Царь-бомба? Сохраняются ли они в постсоветской России, после переименования Арзамаса-16 в Саров?

4. Какую роль играли испытания Царь-бомбы в событиях холодной войны и гонки вооружений? Как эти события влияли на экономическое развитие основных стран-участниц - СССР и США?

7.3. На графике показана динамика мировых цен на нефть (долларов за баррель) в 1970-1980-е гг.

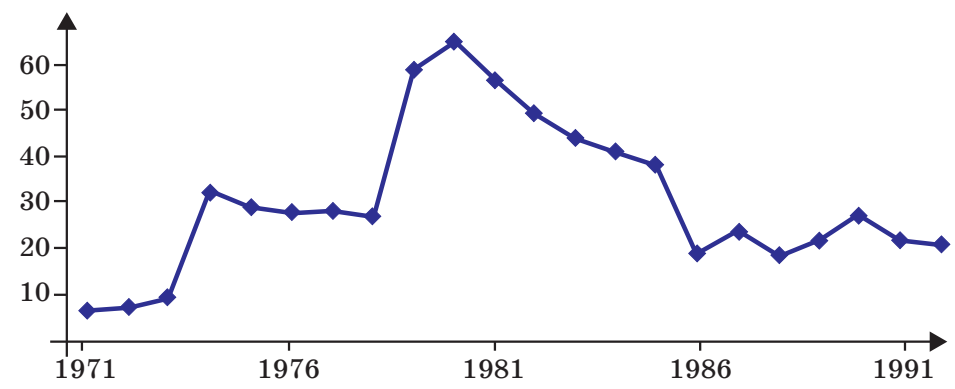


Ответьте на следующие вопросы:

1. Когда и где в СССР начали добывать «большую нефть», что позволило нашей стране стать одним из ведущих «игроков» на мировом рынке энергоресурсов?

2. Почему в 1970-е гг. цены на нефть дважды резко («скачком») выросли? Могло ли это произойти раньше, в предыдущие десятилетия? Связано ли оно с какими-либо действиями Советского Союза?

3. Как в целом повлияло на экономику СССР это резкое повышение мировых цен? Каковы были позитивные и негативные последствия?

4. Почему в 1980-е гг. мировые цены на нефть стали сильно снижаться?

5. Можно ли связать переход от «застоя» к «перестройке» в СССР 1980-х гг. с последствиями падения нефтяных цен?

6. Когда, по каким причинам и с какими последствиями для социально-экономического развития России произошел новый подъем мировых цен на энергоресурсы?

\section{Тесты по экономической истории}

В преподавании экономической истории студентам-первокурсникам в настоящее время активно используются тестовые вопросы множественного выбора, требующие выбрать один (или более) правильный ответ из нескольких предложенных. Такие задания целесообразно применять для контроля знаний как на семинарских заданиях, так и во время финального письменного экзамена. Принципиально важно при этом требовать от студентов не просто указать на правильный по их мнению ответ, но обязательно дать объяснение своему выбору.

Требование решить такие задачи формулируется примерно так: «Выберите правильный ответ (или ответы) из нескольких предложенных. Напишите 
правильный код ответа (например: 1 - в) и кратко объясните, почему Вы выбрали именно его».

Предлагаемые тесты прошли апробацию при преподавании экономической истории в Финансовом университете при Правительстве Российской Федерации.

\section{І. История первобытного общества и древнего мира}

1.1. Второе общественное разделение труда характеризуется выделением в качестве самостоятельного вида хозяйственной деятельности
а) скотоводства;
б) ремесла;
в) земледелия;
г) участия в войнах между племенами.

1.2. Во многих первобытных обществах есть пословица, которая звучит так: «Настоящий вождь умирает...
а) в бою;
б) бедным;
в) от голода;
г) в глубокой старости.

1.3. При дарообмене в позднепервобытном обществе обмен производился с целью
а) разделения труда;
б) поддержания социальных связей и статусов;
в) обмена излишками;
г) сбора дани в пользу бигменов.

1.4. Концепция азиатского способа производства является элементом
а) формационного подхода к изучению истории;
б) цивилизационного подхода к изучению истории;
в) клиометрического подхода;
г) верно и б), и в).

1.5. Особенности развития обществ «азиатского способа производства ученые связывают 
а) с широким развитием товарно-денежных отношений;

б) с необходимостью централизованной организации общественных работ;

в) с необходимостью вести постоянные войны;

г) с очень высокой продуктивностью сельского хозяйства.

1.6. Главный институт обществ «азиатского способа производства» - это

а) «ведомство общественных работ»;

б) патриархальное рабство;

в) власть-собственность;

г) земледельческая община.

1.7. Чего из перечисленного не было в античном обществе?

а) нормирования труда рабов на сельхозработах;

б) применения к рабам методов стимулирования;

в) продажи в рабство свободных граждан за долги;

г) семей у рабов.

1.8. Какую долю трудоспособного населения составляли рабы в период расцвета античного рабства?

a) $10-15 \%$;

б) $30-40 \%$;

в) $60-70 \%$;

г) $85-90 \%$.

1.9. Использования рабского труда в античную эпоху

а) снижало производительность труда из-за незаинтересованности рабов;

б) повышало производительность труда благодаря эффекту экономии на масштабе;

в) верно и а), и б);

г) не верно ни а), ни б). 
1.10. Основная причина постепенного сокращения использования труда рабов в позднеантичном обществе -
а) изобретение сложных орудий труда;
б) сокращение населения из-за эпидемий;
в) крупные восстания рабов;
г) все перечисленное неверно.

1.11. Колон в позднеантичном обществе отличался от раба тем, что
а) имел больше стимулов к труду;
б) находился в личной зависимости;
в) не платил налоги государству;
г) не мог продаваться и покупаться.

1.12. К основным причинам гибели Римской империи следует отнести

a) сокращение притока рабов из-за прекращения завоеваний;

б) восстания рабов;

в) ослабление Великого Шелкового пути;

г) изменение социальной структуры общества.

\section{II. История средних веков}

2.1. Аллод в средние века - это
а) коллективная собственность крестьян;
б) частная собственность свободных горожан;
в) любая наследственная частная собственность;
г) собственность правителя (короля).

2.2. Какое изобретение или институт стало одной из причин формирования в Западной Европе класса-сословия феодалов-рыцарей?
а) длинный меч;
б) наемная армия;
в) конское стремя;
г) магдебургское право. 
2.3. Самым крупным городом Европы в эпоху раннего средневековья (VI-X вв.) был
a) Константинополь;
б) Рим;
в) Лондон;
г) Киев.

2.4. В каком из перечисленных событий или явлений Венеция не участвовала?
а) Крестовые походы;
б) «коммунальная революция»;
в) развитие цехового ремесла;
г) чеканка монет.

2.5. Кто работал в средневековой ремесленной мастерской?
а) только мастера;
б) только мастер и подмастерья;
в) мастер, подмастерья, ученики;
г) мастер, подмастерья, ученики, наемные работНИКИ.

2.6. Что такое «замыкание цехов»?

a) переход к получению звания мастера по наследству;

б) отказ принимать в подмастерья беглых крестьян;

в) переход от работы на заказ к работе на рынок;

г) отказ нанимать на работу жителей других городов.

2.7. Что из перечисленного можно считать одним из последствий эпидемии «черной смерти»?

a) прекращение торговли по Великому Шелковому пути;

б) «коммунальные революции»;

в) прекращение Крестовых походов;

г) начало свертывания крепостного права. 
2.8. Коммутация феодальных повинностей происходила под влиянием
а) «феодальной революции»;
б) «папской революции»;
в) «коммунальной революции»;
г) все предыдущие ответы неверные.

2.9. Какое из перечисленных событий или явлений произошло раньше?
a) начало Крестовых походов;
б) «папская революция»;
в) «феодальная революция»;
г) эпидемия «черной смерти».

2.10. Кто не участвовал в торговле по Великому Шелковому пути?
а) Венеция;
б) Ганза;
в) Индия;
г) Китай.

2.11. Какое изобретение из нижеперечисленных было сделано в Европе раньше, чем на Востоке?
a) огнестрельное оружие;
б) конское стремя;
в) книгопечатание;
г) ни одно из названных.

2.12. Что из перечисленного являлось фактором кризиса феодальной системы?
a) развитие «коммунальных революций»;
б) эпидемия «черной смерти»;
в) потеря крестоносцами земель, завоеванных в Крестовые походы;

в) распространение огнестрельного оружия. 


\section{III. История нового и новейшего времени}

3.1. Основное содержание «первоначального накопления капитала» по К. Марксу - это
а) образование рынка труда;
б) ограбление колоний;
в) образование рынка капиталов;
г) переход от ручного труда к машинному.

3.2. Первая колониальная империя в эпоху Великих географических открытий была создана
а) Венецией;
б) Португалией;
в) Францией;
г) Великобританией.

3.3. Началом промышленного переворота в Англии считается изобретение
а) парового двигателя;
б) паровоза;
в) ткацкого станка с ручным приводом;
г) механического ткацкого станка.

3.4. По современным оценкам, страны Западной Европы обогнали страны Востока (Китай, Индию) по показателям среднедушевого ВНП
а) в XVI-XVII вв.;
б) в начале XVIII в.;
в) в начале XIX в.;
г) в начале $\mathrm{XX}$ в.

3.5. К причинам Гражданской войны в США между Севером и Югом относятся

а) запрет трансатлантической работорговли;

б) противоречие между сторонниками протекционизма и фритредерства;

в) массовые восстания негров-рабов;

г) требования свободного доступа к землям на Западе. 
3.6. Миграция в США из развивающихся стран стала доминировать над миграцией из развитых стран
а) накануне Второй мировой войны;
б) с 1950-х гг.;
в) с 1970-х гг.;
г) с 1990-х гг.

3.7. Какая страна сильнее всего страдала во время Первой мировой войны от морской блокады?
а) Великобритания;
б) Германия;
в) Россия;
г) Франция.

3.8. Обмен бумажных денег на золото прекратился

a) между Первой и Второй мировыми войнами;

б) во время Второй мировой войны;

в) сразу после Второй мировой войны;

г) в 1960-1970-е гг.

3.9. Что из перечисленного не относится к феноменам «неоклассической контрреволюции»?
а) «Новый курс»;
б) «рейганомика»;
в) «тэтчеризм»;
г) «гайдароэкономика».

3.10. Самый сильный мировой экономический кризис в период после Второй мировой войны связан с

a) «пузырем» на рынках недвижимости;

б) шоком на рынках энергоресурсов;

в) последствиями аварий атомных электростанций;

г) ошибками администрации ЕС.

\section{IV. История России досоветского периода}

4.1. Образование Древнерусского государства наиболее хорошо объясняется

а) договорной теорией Дж. Бьюкенена; 
б) теорией оседлого бандита М. Олсона;

в) теорией «стадий роста» У. У. Ростоу;

г) мир-системной концепцией И. Валлерстайна;

д) теорией классовых конфликтов К. Маркса.

4.2. Из какой из перечисленных стран Россия никогда не пыталась осуществить импорта институтов?

а) Византия;

б) Турецкая империя;

в) Голландия;

г) Китай;

д) Швеция.

4.3. Какой вариант правильно перечисляет по нисходящей (т. е. по критерию снижения социального статуса) категории населения в Киевской Руси?

а) князь - смерд - огнищанин - холоп;

б) холоп - смерд - закуп - огнищанин;

в) смерд - закуп - огнищанин - холоп;

г) закуп - князь - холоп - огнищанин.

д) огнищанин - смерд - закуп - холоп.

4.4. Какие процессы происходили в Западной Европе в то время как на Руси было «монголо-татарское иго»?

a) Реформация, войны католиков и протестантов;

б) Возрождение;

в) «коммунальные революции», появление самоуправляющихся городов;

г) превращение свободных земледельцев в крепостных крестьян;

д) формирование и распад империи Карла Великого.

4.5. Действие закона Грэшема стало в правление царя Алексея Михайловича причиной

а) Соляного бунта;

б) Медного бунта; 
в) Соловецкого сидения;

г) Псковского восстания;

д) восстания Степана Разина.

4.6. Что из перечисленного было одной из предпосылок Раскола?

а) «первоначальное накопление капитала» в Западной Европе;

б) развитие внутренней торговли;

в) распространение книгопечатания;

г) проникновение в Московское царство идей протестантизма;

д) установление крепостного права.

4.7. Чего из перечисленного не было в России XVII в.?
а) бумажных денег;
б) медных денег;
в) торговли с Великобританией;
г) мануфактур;
д) наемного труда.

4.8. Зачем в XVII в. Московское царство завоевывало Сибирь?

а) чтобы защититься от грабительских набегов;

б) чтобы добывать серебро и другие полезные ископаемые;

в) чтобы открыть торговый путь на Восток, в Китай и Японию;

г) чтобы добывать для экспорта в Европу пушнину и «рыбий зуб»;

д) чтобы раздавать новые земли дворянам.

4.9. Первую в России крупную Николаевскую железную дорогу (именно об этой дороге Москва Санкт-Петербург писал Некрасов в «Железной дороге») строили в основном 
a) крепостные крестьяне, отбывающие барщину;

б) крепостные крестьяне на оброке;

в) рабочие, нанятые за рубежом;

г) осужденные преступники;

д) солдаты.

4.10. Что относится к реформам П. А. Столыпина?

а) переселенческая политика;

б) укрепление рубля;

в) «черный передел»;

г) «белый передел»;

д) прекращение переделов земли.

\section{V. История России советского периода}

5.1. Какие ранее не применявшиеся в России методы огосударствления экономики использовали большевики во время «военного коммунизма»?

а) продразверстка;

б) национализация промышленных предприятий, производящих стратегическую продукцию;

в) пайковое нормирование потребления населением продуктов питания;

г) первоочередное обеспечение нужд армии в ущерб производству гражданской продукции;

г) все перечисленное появилось еще до прихода к власти большевиков.

5.2. Главная причина коллективизации в СССР это необходимость

а) увеличить урожайность;

б) увеличить импорт продовольствия;

в) «перелить» ресурсы сельского хозяйства в промышленность;

г) освоить Сибирь за счет заключенных ГУЛАГа;

д) пресечь массовые протестные выступления крестьян про советской власти. 
5.3. По каким из перечисленных видов продукции поставки по ленд-лизу имели существенное значение для СССР?
а) марганцевая руда;
б) аллюминий;
в) консервы;
г) зерно, хлеб, мука;
д) боеприпасы (патроны, снаряды).

5.4. Во второй половине 1940-х гг. в СССР

a) проводилась замена министерств совнархозами;

б) запущен первый искусственный спутник;

в) проводилась денежная реформа, подготовившая отмену карточек на продукты;

г) началось освоение целины;

д) началось освоение нефтегазовых месторождений Сибири.

5.5. Послевоенный экономический рост СССР характеризовался
а) использованием ленд-лиза;
б) получением репараций с Германии;
в) использованием внешних займов;
г) планово-директивным управлением;
д) реализацией внутренних госзаймов.

5.6. Городское население СССР превысило сельское население
a) в 1970-е;
б) в 1960-е;
в) в 1950-е;
г) в 1930-е;
д) в 1920-е.

5.7. Что из перечисленного относится к крупным экономическим проектам периода правления Н. С. Хрущева? 
а) Днепрогэс;

б) Магнитогорск;

в) атомный проект;

г) освоение целины;

д) космическая программа.

5.8. Лозунгами реформы А. Косыгина были

а) 2 «A»- автономия, автоматизация;

б) 3 «С»- самоокупаемость, самофинансирование, самоуправление;

в) 4 «П»- порядок, платежи, перестройка, приватизация;

г) 4 «М»- модернизация, мелиорация, миниатюризация, маневренность,

д) 5 «Р»- рост, развитие, рационализация, разоружение, реформа.

5.9. Одной из причин свертывания реформы А. Косыгина считают «ресурсное проклятие», связанное с...

а) нехваткой ресурсов,

б) падением мировых цен на сырьевые ресурсы;

в) появлением качественно новых ресурсов;

г) ростом мировых цен на сырьевые ресурсы;

д) ростом ресуросоемкости производства.

5.10. «Застой» при Л. И. Брежневе проявлялся в...

а) снижении доходов;

б) росте дефицита товаров;

в) увеличении безработицы;

г) депопуляции населения;

д) росте сроков эксплуатации оборудования.

\section{Информация об авторе}

Латов Юрий Валерьевич - доктор социологических наук, кандидат экономических наук, ведущий научный сотрудник, Институт социологии РАН; профес- 
сор, департамент экономической теории, Финансовый университет при Правительстве РФ, 125993, г. Москва, Ленинградский проспект, 49, e-mail: latov@mail.ru.

\section{Author}

Yury V. Latov - D.Sc. in Sociology, Ph.D. in Economics, Leading Researcher, Institute of Sociology RAS; Professor, Department of Economic Theory, Financial University under the Government of the Russian Federation, 49, Leningradsky Prospekt, Moscow, Russian Federation, 125993, e-mail: latov@mail.ru.

\section{Библиографиическое описание статьи}

Латов Ю. В. Творческие задания по экономической истории / Ю. В. Латов // Историко-экономические исследования. - 2017. - Т. 18, № 1. - С. 155-189. DOI: 10.17150/2308-2588.2017.18(1).155-189.

\section{Reference to article}

Latov Yu. V. Creative tasks on economic history. Istoriko-ekonomicheskie issledovaniya = Journal of Economic History \& History of Economics, 2017, vol. 18, no. 1, pp. 155-189. DOI: 10.17150/2308-2588.2017.18(1).155-189. (In Russian). 